\title{
ACCOUNTABILITY REQUIREMENTS, AUDITING PERFORMANCE, AND GENDER
}

\author{
Heince R. N. Wokas ${ }^{1}$, David P. E. Saerang ${ }^{2}$, Jantje J. Tinangon ${ }^{2}$, Ivonne S. Saerang ${ }^{3}$ \\ ${ }^{1,2}$ Accounting Department, Faculty of Economics and Business, Sam Ratulangi University, Jl. Kampus Bahu, \\ Manado, 95115, Indonesia \\ ${ }^{3}$ Management Department, Faculty of Economics and Business, Sam Ratulangi University, Jl. Kampus Bahu, \\ Manado, 95115, Indonesia \\ ${ }^{1}$ Corresponding e-mail: heince_wokas@unsrat.ac.id
}

\begin{abstract}
The purpose of this study is to identify the different types of accountability requirements and to determine whether the workload and pressure of accountability requirements affect the auditing performance of the internal auditors' Government Internal Supervisory Apparatus (or called APIP) the Regional Government Inspectorate in North Sulawesi, Indonesia both women and men, with Partial Least Squares (PLS) modeling as an analysis tool used in analyzing and interpreting the data. The results of the study using quantitative analysis showed that the auditing performance of the APIP in North Sulawesi was partly influenced by the negative perceptions of work context in the form of workload and work pressure. The auditing performance is not affected by the dimensions of accountability requirements, work pressure affects the auditing performance, and so does the gender that does not affect the auditing performance.
\end{abstract}

Keywords: accountability requirements; workload; work pressure; gender and performance JEL Classification: H11, M42, M48

Article info:

Received 7 July 2020

Revised 15 October 2020

Accepted 15 October 2020

Available online 15 October 2020

\section{INTRODUCTION}

The quality of an auditing performance can be influenced by the sense of accountability of an auditor in carrying out the auditing work. Accountability is as a form of psychological encouragement that encourages someone to try to account for all the actions and decisions taken regarding the enforcement mechanisms and norms in his daily environment (Tetlock, 1985). There have been many studies that proved the relationship and the effects of one's accountability on the quality of work. Tan and Kao (1999) state that accountability has an impact on the quality of work. Saerang (2003) examines that accountability in a religious organization that reveals the existence of a higher principal. Messier and Quilliam (1992) revealed that the auditor's accountability may improve the auditor's cognitive process in making decisions. Tetlock and Kim (1987) also examine the issue of auditor's accountability in carrying out an auditing task. Their research proves that those who believe that their works will be examined by their superiors will produce higher quality results, compared to those who will not be examined by their superiors. They will carry out a more complete cognitive processes, provide a more appropriate response, and report decisions that are more reliable and realistic. Chaiken (1980) conducted a research on the accountability of a person in relation to something he liked and didn't like. This study indicated that the subject that has high accountability, always taking actions based on 
rational, not merely on something that he likes or don't like. Posner (2000) states that the obligation to account for the behavior and management of the expectations of various types of accountability in various ways has become an unsolved problem for public institutions. It is caused by the excessive pressure on one set of forms of accountability requirements (Dubnick, 2005; Johnston and Romzek, 1999; Romzek and Dubnick, 1987).

According to Johnston and Romzek (1999), there are four types of accountability, namely hierarchical accountability, legal accountability, professional accountability, and political accountability. The research model above assumes the four types of accountability requirements affect the workload and work pressure as felt by The Government Internal Supervisory Apparatus (or called APIP), which in turn influences their perceptions of their work performance. In this study, the accountability requirements can be defined as an impetus for the auditing performance which is required by APIP in achieving the expectations based on the various types of accountability (Kim and Lee, 2009). In the context of the organizations in the nonprofit sector, Kim and Lee (2009) suggest that performance can be defined as a fulfilling of the organization's mission. The indications of the perception of accountability as a necessity in managing the expectations of the various types of accountability in the Indonesian government are indicated in the research conducted by Akbar et al. (2012) which state that the factors that cause the local governments to implement accountability are due to the legislative obligations and a strong pressure from the central government. Therefore, it is very important to re-examine the type of accountability requirements on the work performance of the Government Internal Supervisory Apparatus (APIP), to fill the gap of the previous studies based on the institutional theory and theory of cognitive dissonance in order to explain the phenomena that occurred both in men and women within the scope of the local government of Indonesian.

\section{LITERATURE REVIEWS}

Institutional theory is based on the idea that in order to survive, an organization must be able to convince the public or the community that the organization is legal and deserves to be supported (Meyer and Rowan, 1977; Scott, 2008; Villadsen, 2011). Institutional theory holds the belief that organizations that prioritized legitimacy will have a tendency to try to make adjustments to the external expectations or social expectations (DiMaggio and Powell 1983; Frumkin and Galaskiewicz, 2004; Ashworth et al., 2009), where the organization is located. The adjustments to the external expectations or social expectations result in the tendency of the organizations to separate their internal activities and focus on the systems that are symbolic to the external parties (Meyer and Rowan, 1977). The public organizations that tend to gain legitimacy will tend to have similarities or isomorphism with other public organizations (DiMaggio and Powell, 1983).

Cognitive dissonance theory is a theory that discusses a person's feelings of discomfort caused by inconsistent attitudes, thoughts and behaviors, and motivates a person to take steps to reduce the discomfort. Dissonance is a feeling that is felt when someone commits to himself to carry out an action that is not consistent with his other behaviors and beliefs (East, 1997). In this theory, 'consistency' and 'inconsistency' have the connotation meaning of something that is unwanted. Therefore, Festinger (1957) argues that dissonance occurs when there is a contradictory relationship, which is caused by the denial of one cognitive element against another, between cognitive elements in an individual. The opposite relationship occurs when there is a denial between the cognitive elements of one another.

Quality internal audit results indicate a good and responsible supervision and management of government finances. In Indonesia the function of internal supervision in the government's internal audit is carried out by the Government Internal Supervisory Apparatus (or called APIP), namely the Inspectorate. In accordance with the provisions of the 
Government Regulation number 41 in year of 2007, the Inspectorate is an organizing supervisory element of the regional government administration. The Inspectorate has the functions of supervisory program planning, policy formulation and supervision facilitation, auditing, investigating, examining, and the assessment of supervisory tasks. Table 1 presents the model applied for this study which developed based on theoretical concept of accountability as proposed by Johnston and Romzek (1999), and Kim and Lee (2009).

Table 1. Types of the accountability pressures

\begin{tabular}{ccc}
\hline Degree of Autonomy & \multicolumn{2}{c}{ Source of Expectation and/or Control } \\
\cline { 2 - 3 } & Internal & External \\
\hline Low & 1.Hierarchical & 2.Legal \\
High & 3.Professional & 4.Political \\
\hline
\end{tabular}

Source: Johnston and Romzek (1999)

The hierarchical accountability requirements, workload, and work pressure. The hierarchical accountability requirements refers to a strict supervision of the internal auditors under a higher authority with an internal control as a unitary institution that emphasizes a command chain based on the structure as a form of subordinate adherence to superiors (Romzek, 2000) through various organizational and regulatory rules, directives, and performance standards (Kim and Lee, 2009). The hierarchical accountability pressure causes the internal auditors to obey the directions, instructions of their superiors, and spending more time in reaching the expectations of their superiors by leaving their main tasks in the organization (Kim and Lee, 2009), involved in a role conflict (Fry, 1995) that causing a psychological pressure in achieving certain expectations. In addition to their roles above, due to their low degree of autonomy, the internal auditors do not have the power in making decisions in relation to the priority of their duties and responding to these conditions as an expansion of work in the form of work accumulation or the addition of work (Houston et al., 2006). This hierarchical requirement may negatively affect the performance of the internal auditors, because the supervision by the superiors does not only produce significant workload but also work pressure by enforcing various performance appraisal regulations, performance standard regulations, various reporting requirements, and also creates tension between superiors and the internal auditors that ultimately causing the feeling of inconvenience to the auditors. Based on the theory of cognitive dissonance, if there were any inconvenience caused by the hierarchical accountability pressures, the person then will take steps to reduce the discomfort. Based on the theoretical background and arguments above, the hypotheses developed are:

Hla: The hierarchical accountability requirement is positively related to workload.

$H 1 b$ : The hierarchical accountability requirement is positively related to work pressure.

Legal accountability requirement, workload and work pressure. The legal accountability requirement refers to the relationship between the internal auditors in terms of compliance to the external supervision through the efforts of strengthening the work mandate, reflecting the details of the external supervision to the performance of the internal auditors with the aim at regulating the contractual relationships. The external parties make the regulations and policies, and then the inspectorate as the institutional part, carrying out and implementing the mandate, without considering the knowledge and skills of the internal auditors as the accountability actors (Romzek and Dubnick, 1987; Romzek and Ingraham, 2000). In the context of local government, the legal accountability is realized through the regulations and laws as a form of obedience to the mandate grantor, for example through the Presidential Instruction Number: 7 of 1999 concerning the Performance Accountability 
Reports of the Government Agencies (LAKIP), the Government Regulation No. 71 of 2010 concerning the Accrual Accounting, the implementation of the accounting system in accordance with Minister of Home Affairs regulation no 64 of 2013. The lack of consideration of the skills and knowledge possessed by the internal auditors affects the perception of workload. It is caused by the obligation of the internal auditors that are required the external expectations which are not in accordance with the abilities of the auditors and the needs of the institution (Romzek, 2000). The legal accountability requirements also affects the work pressure, because the auditors perceive that they have strayed from the organization's main goals, namely providing services to the community, altruistic care and adherence to the internal standards, and are more concerned with the technical matters in achieving the external regulatory demands (Kim and Lee, 2009). Therefore, if the internal auditor find out a discrepancy between the accounting report to the applicable rules, and the auditor does not report or ignore it, the auditor then will face a legal consequence. As a result, the internal auditor will make some adjustments to the report, to avoid legal issues. Based on the theoretical background and the arguments above, the hypotheses developed are:

H2a: The legal accountability requirement has a positive effects on workload.

$H 2 b$ : The legal accountability requirement has a positive effects on work pressure.

Professional accountability requirement, workload, and work pressure. The Professional Accountability Requirement expects the internal auditors to work based on their expertise, professional norms and standards, (Kim and Lee, 2009). The Inspectorate as an institution authorized to carry out financial supervision, should be able to prevent and protect the local government assets from fraud, and should be professional in providing services to clients, in this case the auditees, with a strong ethical awareness, and care in all services provided, in an effort to improve the financial statements of the Regional work units (SKPD). The Professional Accountability Requirement for the internal auditors are reflected in proper work governance, and are more influenced by the internal values and norms, compared to the political influence with the aim of achieving certain work performances which is consistent with the norms, derived from professional socialization, personal beliefs, organizational culture, and from work experience (Romzek, 2000), led them to make the right decisions, even without the directives of their superiors, and/or based on regulatory requirements (Ha and Hoch, 1989). In some cases, professional auditors often face difficult situations, when they are serving the auditee, they may sometimes be inconsistent with the directions of their superiors or legal mandate, thus making the internal auditors feel uncomfortable and taking some actions to reduce the discomfort, in accordance with the theory of cognitive dissonance. For example, many human service agents are urged to be more professional in response to the terms and expectations of the government contracts (Smith and Lipsky, 1993). However, with the expertise of the internal auditors obtained from tiered training may be able to reduce the workload and work pressure faced, because the auditor works with high professional standards of autonomy for decision making with the recognition of expertise by the higher autonomy (Kim and Lee, 2009). Based on the theoretical background and the arguments above, the hypotheses developed are:

H3a: The professional accountability requirement has a positive effects on workload. $H 3 b$ : The professional accountability requirement is positive related to work pressure.

Political accountability requirement, workload and work pressure. The political accountability requirement refers to the responsiveness to the key institutional stakeholders such as clients, government, society, the media and the legislature (Kim and Lee, 2009). The essence is the responsibility of the inspectorate institution in responding and anticipating the agenda, and the expectations of the various stakeholders that exceed the scope of the 
supervisor-subordinate or professional expertise (Romzek, 2000). Based on the institutional concept, one of the forms of the political accountability is that, it must be carried out through the supervision process of the Development Planning Conference (Musrenbang). As an institution that oversees the process of Musrembang implementation, the inspectorate follows and provides input up to the joint discussions stage with the DPRD, so that it becomes a pressure for the SKPD, because it is more influenced by the political conditions at the time, namely how the political relations between the local government and the DPRD. The political accountability requirement affects the workload, because the fulfillment of the expectations is more than the limits of expertise and the direction of superiors (Romzek, 2000). For example, the demands from the advocacy groups and local media related to the transparency in financial management may divert the attention of the internal auditors fin fulfilling the organization's mission through social activities to maintain community relations. The responsiveness to these conflicting demands from various constituencies msy jeopardize the performance by the increasing of the employee perceptions of workload and work pressure (Kim and Lee, 2009). In addition, political accountability may impact on work pressure, due to the fulfillment of responsibilities, reflecting the needs for legitimacy that is very dependent on how well the internal auditors performs their works and reaches stakeholder expectations, and whether the inspectorate is perceived as a co-worker (Romzek and Ingraham, 2000). Based on the theoretical background and the arguments above, the hypotheses developed are:

H4a: The political accountability requirement is positively related to workload.

$H 4 b$ : The political accountability requirement is positively related to work pressure. H4c: Workload is positively related to work pressure.

Workload, work pressure, and work performance. The workload and pressure of the accountability requirements tend to weaken the role of the intetnal auditors due to the implementation of administrative functions that must be met and the large amount of transaction evidence that must be reviewed as a result of the accountability requirement, leading to an increase of negative perceptions in the work context (Kim and Lee, 2009). Actually, the work context can be perceived either negatively or positively. This differences may effect on work outcomes or work performance at different levels (Lusch and Serpkenci, 1990). However, in this study, the work context is perceived negatively in the form of work pressure and workload due to the requirements of accountability (Kim and Lee, 2009). The internal auditors may respond to it as a form of work accumulation or aditional work, and not as a form of work adaptation (Houston et al., 2006). If the various types of accountability is perceived as an expansion of work, and the lack of authority that determines the type of accountability that must be prioritized, then the internal auditors will treat each type of the accountability requirements the same, that later will affect the auditor's audit performance (Kim and Lee, 2009). This work pressure tends to create value dissonance that may hurt their professional calls or their ethical obligation in providing services to the community. For example, Johnston and Romzek (1999) found that, even though they had a high level of commitment to provide quality services, they were frustrated by the document and documentary requirements as they have to comply with contractual obligations that could jeopardize the agent's mission to serve clients. On the other side, Kim and Lee, (2009) find that the documentation and reporting requirements increased the workload of the nonprofit health service employees, and seeing it as an important part of their work. They tend to have the perception that their work is not valued, due to the fact that they are forced to allocate their time that should be used to serve the community (Light, 2000; Salamon, 2002). The perception of high workloads and work pressure simultaneiusly by APIP may negatively influence their perception of performance. Based on the theoretical background and the arguments above, the hypotheses developed are: 
H5a: Workload is negatively related to work performance.

H5b: Work pressure is negatively related to work performance.

The relations between gender and performance. According to Schwartz (1997), the field of public accounting is one of the most difficult areas of work for the women due to the intensity of the work. However, this field is a field that is very potential for the development, and these changes or development may increase the employment of women. Schwartz (1997) also revealed that it is very easy to find out why there are fewer women as partners, compared to men. One of the reasons he put forward is the existence of culture created for men (patriarchy), and then there is also a stereotype of women, especially the opinion that women have an attachment (commitment) to the family which is greater than the attachment (commitment) to a career. According to Jamilah et al. (2007), gender is thought to be one of the individual level factors that may also affects the quality of the work of the internal auditors along with the changes in the complexity of the work and the effect of the level of compliance to the ethics. The findings of cognitive psychological literature and marketing research also states that women are thought to be more efficient and effective in processing information when there is a complexity of tasks in decision making, compared to men. Ruegger and King (1992) state that women are generally have a higher level of moral judgment than men.

Hypothesis 6: Gender affects the relationship of workload and work pressure on performance

\section{RESEARCH METHOD}

This study applied Partial Least Square (PLS) testing model to test the hypotheses as described in Figure 1. The object of this study is the State Civil Apparatus (ASN) who works in the Inspectorate office as the Government Internal Supervisory Apparatus (APIP), in this case the internal auditors who has served for at least 1 year in that position at the Inspectorate in the regencies/cities in North Sulawesi. The total are 15 Inspectorate offices, spread across 15 regencies/cities. The number of samples of this study were 150 samples, returned 125, and 17 samples of data were incomplete, so there were only 108 samples that could be processed. The data obtained from 15 SKPD of 15 regencies in North Sulawesi Province. Data collected or obtained by filling out questionnaires, and then measured by using a Likert scale, distributed to the internal auditors working in the regencies and city Inspectorate offices in North Sulawesi Province. Most of the respondents were young people and productive, ranging from 20 to 39 years. The lowest level of education of the respondents is high school, and the highest is Master degree, meanwhile the length of time they worked was $10.2 \%$ over 5 years, $71.3 \%$ of auditors worked between 2 to 5 years, and $18.5 \%$ under 2 years. While for the group positions, 87 respondents or $80 \%$ were skilled auditors, and the remaining of 21 respondents were P2UPD or $20 \%$. 


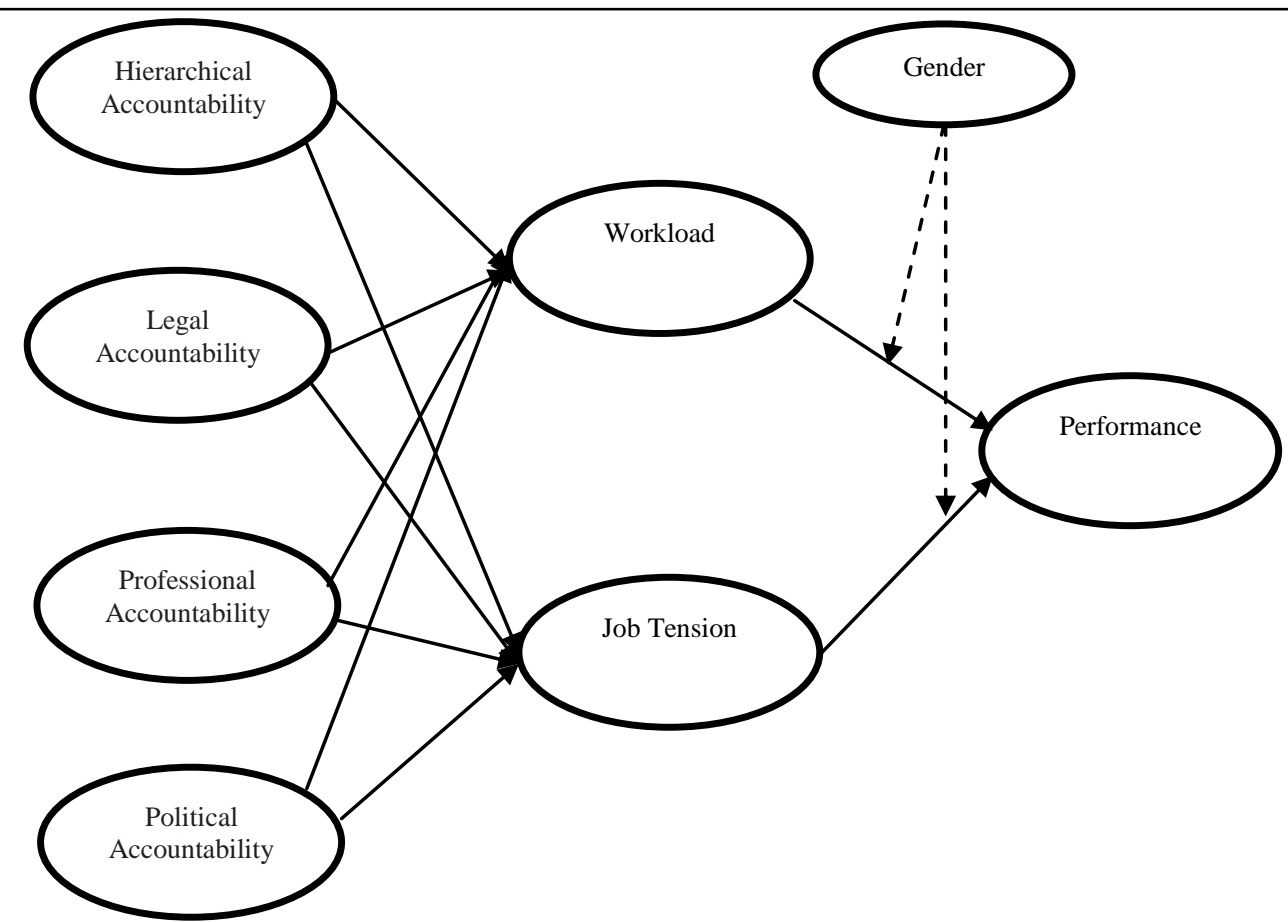

Figure 1. Research Model

\section{RESULTS AND DISCUSSIONS}

\subsection{Results}

Validity test consists of convergent validity through AVE and Communality scores with a criteria $>0.5$, and discriminant validity through cross loading scores with a criteria $>0$, but 0.5-0.7 scores are still acceptable if AVE values> 0.5 (Hair et al., 2010). Reliability test can see in the Composite Reliability score with the criteria> 0.6.

Table 2. Overview iteration Algorithm PLS

\begin{tabular}{cccccc}
\hline & Cronbach's Alpha & rho_A & R Square & CR & AVE \\
\hline HA & 0.542 & 0.785 & & 0.739 & 0.501 \\
LA & 0.640 & 0.673 & & 0.773 & 0.418 \\
ProA & 0.850 & 0.898 & & 0.890 & 0.622 \\
PolA & 0.740 & 0.794 & & 0.846 & 0.648 \\
M & 1.000 & 1.000 & & 1.000 & 1.000 \\
WL & 0.843 & 0.846 & 0.118 & 0.906 & 0.763 \\
WP & 0.774 & 0.812 & 0.324 & 0.872 & 0.699 \\
Pf & 0.737 & 0.740 & 0.214 & 0.835 & 0.558 \\
\hline
\end{tabular}

In Table 2 Overview of iteration algorithm, it can be seen that the research instrument can be declared valid and reliable. Hair et al. (2010) suggest that the usual rule of thumb used to make an initial examination of the matrix factor is that +30 that is considered to have fulfilled the minimum level for loading +40 is considered better, and for loading $>0.50$ is considered to be practically significant. Convergent validity test can be seen from the AVE value, the variables in this study already have an in Table 2 it can be seen that the value of the workload construct (BK) is 0.118 , the work pressure construct (TK) is 0.324 , and the performance construct $(\mathrm{K})$ is 0.214 . That means that the proposed research model is able to explain the variable workload construct by $11.8 \%$, the work pressure construct by $32 \%$, the performance construct by $21.4 \%$, and the rest is explained by the other variables outside the model of this study. 
Table 3. Total effect

\begin{tabular}{cccc}
\hline Correlation & Original Sample $(\mathbf{O})$ & T Statistics & P Values \\
\hline HA ->WL & 0.134 & 0.898 & 0.370 \\
HA -> WP & 0.168 & 1.268 & 0.205 \\
LA ->WL & 0.251 & 2.786 & 0.006 \\
LA -> WP & 0.353 & 4.034 & 0.000 \\
PA. - - WL & 0.008 & 0.002 & 0.998 \\
PA -> WP & 0.239 & 2.189 & 0.029 \\
PoA -> WL & 0.046 & 0.327 & 0.744 \\
PoA -> WP & 0.096 & 0.870 & 0.384 \\
M -> Pf & -0.011 & 0.109 & 0.913 \\
WL ->Pf & 0.029 & 0.257 & 0.797 \\
WP ->Pf & 0.425 & 3.004 & 0.003 \\
\hline
\end{tabular}

The results of testing using the bootstrapping technique in Table 3 show that of the eleven hypotheses being tested, six hypotheses are statistically supported because they had a T-statistic value, higher than the value of the T-table, i.e. $\geq 1.64$ (alpha $=5$ percent). The three supported hypotheses are: $2 \mathrm{a}(\mathrm{LA} \rightarrow \mathrm{WL})$ with a T-statistic value of 2.786 , and a path coefficient $(\gamma 1)$ value of 0.251 ; hypothesis $2 \mathrm{~b}(\mathrm{LA} \rightarrow \mathrm{WP})$ with a T-statistic value of 4.034, and a path coefficient $(\gamma 1)$ value of 0.353 ; while the unsupported hypothesis is hypothesis 1a $(\mathrm{HA} \rightarrow \mathrm{WL})$ with a value of T-statistic value of 0.898 , and a path coefficient $(\gamma 1)$ value of 0.134 ; hypothesis $1 \mathrm{~b}(\mathrm{AH} \rightarrow \mathrm{WP})$ with a value of T-statistic value of 1,268 , and a path coefficient $(\gamma 1)$ value of 0.168 ; not empirically supported because the T-statistic value is lower than the T-table value (1.64) as well as hypothesis $3 \mathrm{a}(\mathrm{PA} \rightarrow \mathrm{WL})$ with a $\mathrm{T}$ statistic value of 0.002 , and a path coefficient $(\gamma 1)$ value of 0.008 ; while hypothesis $3 \mathrm{~b}(\mathrm{PA} \rightarrow \mathrm{WP})$ although proven to be significant, this hypothesis is not supported with a $\mathrm{T}$ statistic value of 2.189 , and a path coefficient $(\gamma 1)$ value of 0.239 ; for hypotheses $4 \mathrm{a}(\mathrm{PoA} \rightarrow \mathrm{WL})$ with a Tstatistic value of 0.327 , and a path coefficient $(\gamma 1)$ value of 0.046 ; hypotheses are: $4 \mathrm{~b}$ (PoA $\rightarrow$ WP) with a T-statistic value of 0.870 , and a path coefficient $(\gamma 1)$ value of 0.096 ; and hypotheses $5 \mathrm{a}(\mathrm{WL} \rightarrow \mathrm{Pf}$ ) with a T-statistic value of 0.257 , and a path coefficient $(\gamma 1)$ value of 0.029 ; hypotheses $6(\mathrm{M} \rightarrow \mathrm{Pf})$ with a T-statistic value of 0.3109 , and a path coefficient $(\gamma 1)$ value of 0.011 . Not empirically supported because the T-statistic value is lower than the T-table value (1.64), while hypothesis $5 \mathrm{~b}(\mathrm{WP} \rightarrow \mathrm{Pf}$ ) with a T-statistic value of 3.004 , and a path coefficient $(\gamma 1)$ value of 0.425 even though significantly proven but does not support the hypothesis.

\subsection{Discussions}

According to Romzek and Dubnick (1987), the hierarchical accountability (high internal control) is a hierarchical arrangement based on the organizational supervisions and instructions. Therefore, efficiency then becomes the most priority value, and the adherence to the organizational rules is an expectation of an individual behavior. This study found that hierarchical accountability does not affect the workload and work pressure of APIP in North Sulawesi, this shows that there is awareness of the APIP as the auditors of the organizational rules assigned to guarantee the financial accountability within the local government environment, by upholding the principle of professionalism as a professional auditor. The auditors are aware of the fact that the tasks assigned will be evaluated by their superiors so that the works carried out so far are not considered as a burden. When the superior asks for an accountability of a task given, the audit report is made available according to the instructions or directions given by the superior, it means that in carrying out the work, the instructions and directives become the guidelines for the worksthat have been done. Every form of policy given to subordinates by the superiors will be done as well and as good as possible in order to 
show their loyalty to the superiors as a bureaucrat who obeys to the leadership, According to Romzek (2000), this kind of work pattern is built based on the relationship of subordinatesuperiors. Therefore, the superiors would provide good judgement when the subordinates follows the orders or instructions given by the superiors. This situation was also stated by DiMaggio and Powell (1983), who stated that such a pattern was derived from the institutional isomorphic. Meanwhile the accountability requirement is seen as an obligation to explain and justify the behavior of an internal auditor, namely answerability (Bovens, 1998) for what that has been directed by the superiors. Most of them will try to fulfill the demands of their superiors, so that their autonomy will be reduced along with thecompliance, because they prioritize their superiors. Even in the case of poor quality supervision, feedback about inadequate work performance, inadequate authority to carry out responsibilities, does not become a pressure for the internal auditors. They always race to get a good assessment when the evaluation is carried out by their superiors, which are then becomes the motivation for them in carrying out the work better. The result of this study supports the institutional theory which state that in an organization, the adherence to superiors is the reason for APIP in carrying out the audit tasks.

According to Romzek and Dubnick (1987), the legal accountability (high external control) is achieved through contractual agreements. Based on this type of accountability, the obedience to the law is the most important value, and the adherence to the external mandates becomes the expectation of each individual behavior. The results of hypothesis test indicate that the legal accountability has a significant and positive effect on workload. This means that the legal accountability will increase the APIP workload. Workload arises when the superior discretion arises over the disclosure of the results of audit results. The policy of the superiors to cover up the results of auditing works or not disclose the results of the audit report, may causes conflicts within APIP. The inability of the internal auditors to refuse to the intervention of and the will of their superiors, may cause a loss of independence in their audit reports, And this is a phenomenon that often occurs in the local government bureaucratic system in North Sulawesi, It is due to the fact that the internal auditor may assumed that his "destiny" would be on the verge of failure if he does not want to obey the will of his superiors, despite the will is being in contrary to the ethical and professional values of the internal auditor himself. This study support the theory of cognitive dissonance. Furthermore Legal accountability requirement is related to the compliance to the other laws and regulations that are required in running an organization. According to Romzek and Dubnick (1987), the legal accountability requirement (high external control) can be achieved through contractual agreements. Tested result find that the requirement of the legal accountability has a positive effect on work pressure, This may happen due to the loyalty behavior to the superiors who provide a space for negotiation and also a high tolerance for mistakes that usually occur and do not disclose it in the audit report which is known to be in violation to the applicable laws and regulations, thus bringing in the internal auditors or APIP in a depressed condition. Any procedural or regulatory errors will ultimately lead to the legal consequences. Moreover, it has been known that the other institutions would also examine and might find hidden things. These findings are in-line with Johnston and Romzek (1999), who find that "in a contract, there are three most common types of accountability relationships. They are legal, political, and professional, in which the legal accountability being the most common" and consistent with the theory of cognitive dissonance.This study not in-line with Manafe and Akbar (2014) but support the findings of Kim and Lee (2009).

Romzek and Dubnick (1987) state that professional accountability (low internal control) is based on the expertise of a person or work group. According to this type, expertise is the most emphasized aspect, while the appreciation for individual achievements and individual expertise is an individual's expectation. The results of hypothesis test indicate that 
the professional accountability does not affect workload, which means that the ability or capacity of APIP in carrying out their duties is always able to resolve the work demands and uphold professionalism as an internal auditor. The better the professional skills as an APIP, the easier the job to be done, and it is no longer considered as a burden. The repetitive work makes it easier for an internal auditor to complete his work, so that it seems that in carrying out his job, APIP seems to only do his job in order to fulfill his obligations. Meanwhile professional requirement significantly affects work pressure were does not support the hypothesis, showed that the more knowledge possessed by an APIP, the more pressure is placed on its duties as a professional internal auditor who tries to disclose conflicting matters such as material misstatement in the financial statements, procedural errors of responsibility, lack of completeness of the financial accountability files, so that it cannot be disclosed professionally, because it is limited by their superiors to not disclose it in the audit report, which then becomes a pressure in his field of expertise, meaning that an internal auditor loses his independence. The requirements of expertise and accuracy in carrying out tasks are not supported by independence, then it would only be mere a rhetoric. The moral consequence would be a pressure at work due to the fulfillment of expectations is more than the limits of expertise and direction of superiors (Romzek and Ingraham, 2000). This study confirm the institutional theory that in responding to this case, then the auditor will maintain his existence against the external pressure by adjusting himself to the legitimacy given by superiors. The results of study conducted by Tetlock and Kim (1987) that the auditor's accountability issues that are related to the supervisor's examination (preexposure accountability) on the auditor's work, proves that the research subjects in the preexposure accountability group produce a better work than the other groups. The study illustrates the intervention of superiors on the work of the internal auditors that should be adjusted to the goals of the organization.

According to Romzek and Dubnick (1987), the low external control of political accountability which is based on the responsiveness of the elected public officials, customers or clients and other agents; the things that are expected from the accountability are the external interests, The test results show that the political accountability does not affect workload, which means that the political accountability should not be a mandatory for APIP, so that it does not become a burden for them, because they assumed that there are parties who have the right to be asked for the answers or information; the people or entities that have been given the authority to manage certain resources, and being explained by their superiors. So far, the accountability demands from these parties have not become burden on APIP's performance in carrying out the audit works. The requirement for political accountability does not affect work pressure. It is caused by thought oh the internal auditors, in which they think that the results of the audit will be communicated by their superiors, so that the requirement to provide answers to the results of the audit is fully left to their superiors.In the era of regional autonomy and fiscal decentralization, there is a shift in the meeting the needs of legitimacy that led to local governments tending to emphasize the political accountability to the community through the representation of the Regional Representative Council (or called DPRD) which aims to maintain the political legitimacy from the budget process and increase the perception of co-workers (Romzek and Ingraham, 2000). This is because that the accountability is made as a political tool in the form of local government commitment to the legislature and to reach an agreement on the use of public funds (Mardiasmo, 2009), and because of this, the implementation of audits by the internal auditors is often only meets the need for mere duties, and the presence of internal auditors for the implementation of accountability is due to legislative obligations only (Akbar et al., 2012). This result of study confirms the institutional theory that all adjustments or adoptions are the result of normative interpretation. 
This study find that workload does not affect performance which means that APIP in carrying out their tasks are not affected by workload, this is because APIP complies more with the leadership's policies, so they work only to meet the administrative demands. Glaser et al. (1999) find that the size of the workload will not affect the employee performance as long as they do not experience pressure or stress. This matter proved that the APIP in North Sulawesi carries out their tasks only because of the demands of the superiors or as an administrative matter (Akbar et al., 2012). The type of accountability that seems to compete makes APIP confused with their roles. The excessive workload will cause physical and mental fatigue, while in situation where the workload is not too low, such as repetitive tasks will lead to boredom and a sense of monotony. Boredom in daily routine work caused by the working environment makes the APIP not enthusiastic to do their job well, such as negative supervision which results in the work being made just to please the superiors. This study confirms the theory of cognitive dissonance and does not support the findings of Kim and Lee (2009), and Manafe and Akbar (2014). But, work pressure had a significant effect on performanceeven though theresults not supported the hypothesis. It means that work pressure affects APIP in carrying out their duties. Work pressure will arise if there is a gap between an individual's abilities and the demands of his job or task, to reduce the work pressure, then the worker will respond adaptively, as a consequence of actions, situations or external events (environment) that require excessive physical and psychological activities on someone, especially to the auditor both externally and internally, who tend to experience high work pressure (Fogarty et al., 2000). The results of this study confirm the cognitive dissonance theory.

Statistical test results show that gender has no effect on the relationship of work load and pressure on audit performance, which means that no matter how large the burden and work pressure, there is no difference between male auditors or female auditors, because both male and female auditors alike have the same commitment in doing the audit work, but have different satisfaction in producing a quality work. This indicates that either men or women are equally devoted to their abilities and responsibilities as government auditors, so that men or women can produce a quality work regardless of the auditor's gender status. Therefore, gender is not a barrier to producing a quality audit work. According to the theory of gender equality in the equilibrium theory, the difference between men and women is natural, so it must be accepted and not be disputed. These biological differences indicate and imply that the two sexes have different roles and tasks. There are roles and tasks that can be exchanged, but there are those that cannot be exchanged because they are naturally different, in which these biological differences have an influence on instinctual role.That gender differences between male and female auditors as well as differences in characters and traits attached to each individual do not affect the decisions that will be taken, including the audit judgment.

\section{CONCLUSION}

This study provides an empirical evidence about the effects of accountability requirements in the context of work that is negatively perceived by the workload and pressure on the performance of the Government's Internal Supervisory Apparatus (APIP) in the regencies and cities in North Sulawesi. The results of the analysis using the path coefficient analysis, indicates that the auditing performance of the APIP is not negatively related to workload but work pressure can improve auditing performance. APIP prioritizes more on compliance to the legal accountability requirement than to the other accountability (Kim and Lee, 2009), professional accountability is used for adjustments needed due to the pressure and burden caused by the hierarchical and legal accountability, APIP will make the necessary adjustments according to their expertise when various types of accountability requirements are required in carrying out the work both for themselves and for the institution. while the 
political accountability is not a burden and pressure for the APIP, indicating that the burden and pressure of accountability must be at different levels depending on the situation faced by the APIP (Manafe and Akbar, 2014), while for the gender difference factor, it shows that the auditing performance between men and women is no different, despite facing workload and work pressure.

\section{REFERENCES}

Akbar, R., Pilcher, R., \& Perrin, B. (2012). Performance measurement in Indonesia: The case of local government. Pacific Accounting Review, 24(3), 262-291. https://doi.org/10.1108/01140581211283878

Ashworth, R., Boyne, G., \& Delbridge, R. (2009). Escape from the Iron Cage? Organizational change and isomorphic pressures in the public sector. Journal of Public Administration Research and Theory, 19(1), 165-187. https://doi.org/10.1093/jopart/mum038

Bovens, M. (1998). The quest for responsibility: Accountability and citizenship in complex organisations (Theories of institutional design). United Kingdom: Cambridge University Press.

Chaiken, S. (1980). Heuristic versus systematic information processing and the use of source versus message cues in persuasion. Journal of Personality and Social Psychology, $39(5)$, 752-766. https://pdfs.semanticscholar.org/82f3/bd71f38a7b8d2269f1e471e2e8bc300fb880.pdf

DiMaggio, P. J., \& Powell, W. W. (1983). The iron cage revisited: Institutional isomorphism and collective rationality in organizational fields. American Sociological Review, 48(2), 147-160. https://doi.org/10.2307/2095101

Dubnick, M. J. (2005). Accountability and the promise of performance: In search of the mechanisms. Public Performance \& Management Review, 28(3), 376-417. https://www.tandfonline.com/toc/mpmr20/28/3?nav=tocList

East, R. (1997). Consumer behaviour: Advances and applications in marketing. New York: Prentice Hall.

Festinger, L. (1957). A theory of cognitive dissonance. Illinois: Row, Peterson \& Company.

Fogarty, T. J., Singh, J., Rhoads, G. K., \& Moore, G. K. (2000). Antecedents and consequences of burnout in accounting: Beyond the role stress model. Behavioral Research in Accounting, 12, 31-67. https://maaw.info/BehavioralResearchInAccounting.htm

Frumkin, P., \& Galaskiewicz, J. (2004). Institutional isomorphism and public sector organizations. Journal of Public Administration Research and Theory, 14(3), 283307. https://doi.org/10.1093/jopart/muh028

Fry, R. E. (1995). Accountability in organizational life: Problem or opportunity for nonprofits? Nonprofit Management and Leadership, 6(2), 181-195. https://doi.org/10.1002/nml.4130060207

Glaser, D. N., Tatum, B. C., Nebeker, D. M., Sorenson, R. C., \& Aiello, J. R. (1999). Workload and social support: Effects on performance and stress. Human Performance, 12(2), 155-176. https://doi.org/10.1207/s15327043hup1202_4

Ha, Y., \& Hoch, S. J. (1989). Ambiguity, processing strategy, and advertising-evidence interactions, Journal of Consumer Research, 16(3), 354-360. https://doi.org/10.1086/209221

Hair, J. F, Black, B. C., Babin, B. J., Anderson, R. E. (2010). Multivariate data analysis, 7th Edition. New York: Prentice Hall International, Inc. 
Houston, D., Meyer, L. H., \& Paewai, S. (2006). Academic staff workloads and job satisfaction: Expectations and values in Academe. Journal of Higher Education Policy and Management, 28(1), 17-30. https://doi.org/10.1080/13600800500283734

Jamilah, S., Fanani, Z., \& Chandrarin, G. (2007) Pengaruh Gender, Tekanan Ketaatan, dan Kompleksitas Tugas Terhadap Audit Judgment. Simposium Nasional Akuntansi X, Makasar. https://smartaccounting.files.wordpress.com/2011/03/auep06.pdf

Johnston, J. M., \& Romzek, B. S. (1999). Contracting and accountability in state medicaid reform: Rhetoric, theories, and reality. Public Administration Review, 59(5), 383-399. https://doi.org/10.2307/977422

Kim, S. E., \& Lee, J. W. (2009). Impact of competing accountability requirements on perceived work performance. The American Review of Public Administration, 40(1), 100-118. https://doi.org/10.1177/0275074008329469

Light, P. C. (2000). Making nonprofits work: A report on the tides of nonprofit management reform: A report on the tides of nonprofit management reform. Washington, DC: Brookings Institution Press.

Lusch, R. F., \& Serpkenci, R. R. (1990). Personal differences, job tension, job outcomes, and store performance: A study of retail store managers. Journal of Marketing, 54(1), 85101. https://doi.org/10.2307/1252175

Mardiasmo. (2009). Akuntansi sektor publik. Yogyakarta: Andi.

Messier, W. F. Jr., \& Quilliam, W. C. (1992). The effect of accountability on judgement: Development of hypothesis for auditing. Journal of Practice \& Theory, 11, 123-138. https://search.proquest.com/openview/72cfaef9ba49ae5ec329338ecc72acde/1?pqorigsite $=$ gscholar $\& \mathrm{cbl}=31718$

Manafe, M. W. N., \& Akbar, R. (2014). Accountability and performance: Evidence from local government. Journal of Indonesian Economy and Business, 29(1), 56-73. https://doi.org/10.22146/jieb.6213

Meyer, J. W., \& Rowan, B. (1977). Institutionalized organizations: Formal structure as myth and ceremony. American Journal of Sociology, 83(2), 340-363. http://www.jstor.org/stable/2778293

Peraturan Pemerintah Republik Indonesia Nomor 41 tahun 2007 tentang Organisasi Perangkat Daerah.

Peraturan Pemerintah Republik Indonesia Nomor 71 tahun 2010 tentang Standar Akuntansi Pemerintahan

Peraturan Kementerian Dalam Negeri (Permendagri) Nomor 64 tahun 2013 tentang Penerapan Standar Akuntansi Pemerintahan Berbasis Akrual Pada Pemerintah Daerah

Posner, E. A. (2000). Law and social norms: The case of tax compliance review. Journal of Law and Society, 30(4), 609-614. http://www.ericposner.com/Law\%20and\%20Social\%20Norms.pdf

Romzek, B. S. (2000). Dynamics of public sector accountability in an era of reform. International Review of Administrative Sciences, 66(1), 21-44. https://doi.org/10.1177\%2F0020852300661004

Romzek, B. S., \& Dubnick, M. J. (1987). Accountability in the public sector: Lessons from the challenger tragedy. Public Administration Review, 47(3), 227-238. https://doi.org/10.2307/975901

Romzek, B. S., \& Ingraham, P. W. (2000). Cross pressures of accountability: Initiative, command, and failure in the Ron Brown Plane Crash. Public Administration Review, 60(3), 240-253. https://doi.org/10.1111/0033-3352.00084

Ruegger, D., \& King, E. W. (1992). Study of the effect of age and gender upon student business ethics. Journal of Business Ethics, 11, 179-186. https://doi.org/10.1007/BF00871965 
Saerang, D. P. E. (2003). Accountability and accounting in a religious organisation: An interpretive ethnographic study of the Pentecostal Church of Indonesia. Doctor of Philosophy thesis. School of Accounting and Finance, University of Wollongong. https://ro.uow.edu.au/theses/1902

Salamon, L. M. (2002). The state of nonprofit America. Washington, D.C.: Brookings Institution Press.

Scott, W. R. (2008). Approaching adulthood: The maturing of institutional theory. Theory and Society, 37(5), 427-442. https://doi.org/10.1007/s11186-008-9067-z

Schwartz, R. (1997). Legal regimes, audit quality and investment. The Accounting Review, 72(3), 385-406. http://www.jstor.org/stable/248477

Smith, S. R., \& Lipsky, M. (1993). Nonprofits for hire: The welfare state in the age of contracting. Cambridge, MA: Harvard University.

Tetlock, P. E. (1985). Accountability: The neglected social context of judgment and choice. Research In Organizational Behavior, 7, 297-332. http://faculty.haas.berkeley.edu/tetlock/vita/Philip\%20Tetlock/Phil\%20Tetlock/19841987/1985\%20Accountability_Neglected\%20Social\%20Context\%20of\%20Judegmen t.pdf

Tetlock, P. E., \& Kim, J. I. (1987). Accountability and judgment processes in a personality prediction task. Journal of Personality and Social Psychology, 52(4), 700-709. http://faculty.haas.berkeley.edu/tetlock/vita/Philip\%20Tetlock/Phil\%20Tetlock/19841987/1987\%20Accountability\%20and\%20Judgement\%20Processes\%20In\%20a\%20P ersonal.pdf

Tan, H., \& Kao, A. (1999). Accountability effects on auditors' performance: The influence of knowledge, problem-solving ability, and task complexity. Journal of Accounting Research, 37(1), 209-223. https://doi.org/10.2307/2491404

Villadsen, A. R. (2011). Structural embeddedness of political top executives as explanation of policy isomorphism. Journal of Public Administration Research and Theory, 21(4), 573-599. https://doi.org/10.1093/jopart/mur007 